\title{
STUDI ETNOBOTANI DI HUTAN HARAPAN SUKU ANAK DALAM BATIN SEMBILAN DESA BUNGKU KECAMATAN BAJUBANG BATANGHARI PROVINSI JAMBI
}

\section{ETHNOBOTANY STUDY IN HOPE FOREST FOR CHILDREN IN NINE IN NINE VILLAGE BUNGKU VILLAGE, BAJUBANG BATANGHARI DISTRICT, JAMBI PROVINCE}

\author{
Armini Hadriyati ${ }^{1}$, Medi Andriani ${ }^{2}$, Anggeliapratiwi ${ }^{3}$ \\ ${ }^{1}$ Program studi farmasi, Stikes Harapan Ibu, The-Hok, Kota Jambi, Indonesia \\ ${ }^{2}$ Program studi farmasi, Stikes Harapan Ibu, Pakuan Baru, Kota Jambi, Indonesia \\ Koresponding Penulis ${ }^{1}$ arminimuas55gmail.com ${ }^{2}$ mediandriani22@gmail.com ${ }^{3}$ anggeliapratiwi@gmail.com
}

\begin{abstract}
ABSTRAK
Suku Anak Dalam Batin Sembilan merupakan salah satu suku yang berada di Provinsi jambi yang masih memiliki kepercayaan terhadap pengetahuan lokalnya mengenai pengobatan menggunakan tumbuhan tradisional. Penelitian ini bertujuan untuk mengetahui tumbuhan yang bermanfaat sebagai pengobatan serta bagaimana cara pengolahan dan penggunaannya. Jenis penelitian ini adalah kualitatif yang menggunakan metode purposive sampling dan Teknik pengumpulan data yaitu wawancara open-ended interview. Hasil penelitian terdapat 13 tumbuhan yang digunakan Suku Anak Dalam sebagai pengobatan yaitu gaharu, akar mejan, capo, polay, dedaup, akar kelkunyit, pasak bumi, keduduk, melati hutan, akar serekan, daun mempat, meribungan dan sengkuang serta cara pengolahan tumbuhan yaitu dengan cara direbus, direndam dan ditempel dan cara penggunaan yang sering digunakan yaitu diminum dan ditempel. Sedangkan bagian tumbuhan yang digunakan adalah akar, batang, daun dan getah.
\end{abstract}

\section{Kata Kunci: etnobotani, suku anak dalam, purposive sampling}

\begin{abstract}
Suku Anak Dalam Batin Sembilan is one of the tribes in Jambi Province who still have faith in their local knowledge about treatment using traditional plants. This research aims to find out plants that are useful as a treatment and how to process and use them. This type of research is qualitative using a purposive sampling method and data collection techniques, namely open-ended interview. The results of the study there are 13 plants that are used by the Children in the Tribe as a treatment namely gaharu, akar mejan, capo, polay, dedaup, akar kelkunyit, pasak bumi, keduduk, melati hutan, akar serekan, daun mempat, meribungan dan sengkuang as well as a way of processing plants that is by boiling, soaking and pasting and the method of use that is often used is drunk and pasted. While the plant parts used are roots, stems, leaves and sap.
\end{abstract}

Keywords: ethnobotany, tribal children in, purposive sampling 
Journal of Healthcare Technology and Medicine Vol. 6 No. 2 Oktober 2020

Universitas Ubudiyah Indonesia

e-ISSN : 2615-109X

\section{PENDAHULUAN}

Suku Anak Dalam (SAD) merupakan bagian dari kelompok masyarakat terasing yang hidup dipulau Sumatera, tepatnya di Provinsi Jambi. Suku Anak Dalam mengasingkan diri untuk hidup berinteraksi di dalam hutan dengan memanfaatkan sumber daya alam yang ada di dalamnya (Idris, 2017). Hutan Harapan menjadi kawasan prioritas global untuk habitat hutan yang mewakili persen hutan dataran rendah yang tersisa di Sumatera. Sebagian besar kawasan di Hutan Harapan merupakan hutan alam sekunder bernilai tinggi yang tengah dipulihkan. Terdapat banyak flora dan fauna langka yang sulit ditemukan ditempat lain. Selain itu juga menjadi habitat tanaman obat-obatan tradisonal yang sebagian besar belum pernah diteliti secara ilmiah manfaatnya bagi kegunaan manusia. Selain itu Hutan Harapan menjadi tempat tinggal bagi Suku asli Jambi yaitu Suku Anak Dalam Batin Sembilan yang menggantungkan hidupnya dari hasil hutan tersebut (Pujayanti, 2005).

Tujuan dari penelitian ini adalah untuk mengetahui tumbuhan apa saja yang dapat dimanfaatkan sebagai pengobatan serta bagaimana cara penggunaan dan pengolahan tumbuhan tersebut di hutan harapan suku anak dalam batin Sembilan. Kajian yang paling tepat adalah Etnobotani karena melibatkan kajian pengenalan, pengelompokkan dan pengetahuan dari mana obat tesebut dihasilkan, prepasi sediaan obat, aplikasi sediaan obat dan aspek sosial dari penggunaan pengetahuan pengobatan. dalam penelitian etnofarmasi, yang menjadi objek utama penelitian adalah sebuah komunitas yang terisolasi untuk menemukan kembali resep tradisional komunitas tersebut dan mencoba melakukan evaluasi (Fajrin, et al., 2015).

\section{METODE PENELITIAN}

Penelitian ini merupakan penelitian deskriptif yang menggunakan metode kualitatif dan teknik pemilihan sampel yang di gunakan dalam penelitian ini adalah purvosive sampling yaitu teknik sampling non random dimana peneliti menentukan pengambilan sampel dengan cara menetapkan ciri-ciri khusus yang sesuai dengan tujuan penelitian sehingga diharapkan dapat menjawab permasalahan penelitian (Sugiyono, 2017). Sumber data berasal dari hasil wawancara dengan suku anak dalam dengan cara 
Journal of Healthcare Technology and Medicine Vol. 6 No. 2 Oktober 2020

Universitas Ubudiyah Indonesia

e-ISSN : 2615-109X

wawancara yang dilakukan secara open-ended interview bersama temenggung di Suku Anak Dalam. Teknik pengumpulan data berupa wawancara open-ended interview dengan pemilihan sampel Purposive Sampling.

Informan yang dipilih dalam penelitian ini yaitu Temenggung Suku Anak Dalam Batin Sembilan. Diperoleh dari hasil wawancara dan cara pengolahan selanjutnya setiap tumbuhan dilakukan determinasi di Universitas Padjajaran Bandung dengan tujuan mengetahui kebenaran dari nama ilmiah tumbuhan tersebut. Untuk menentukan keabsahan Penelitian kualitatif lebih pada aspek validasi, yaitu temuan atau data dapat dinyatakan valid apabila tidak ada perbedaan antara yang dilaporkan peneliti dengan apa yang sesungguhnya terjadi pada obyek yang diteliti (Sugiyono, 2016).

\section{HASIL DAN PEMBAHASAN}

Dari hasil wawancara dengan informan, penyakit yang sering terjadi pada masyarakat Batin Sembilan ini adalah demam, batuk serta panas dalam yang mana pada dasarnya masyarakat Suku Anak Dalam Batin Sembilan ini jarang sakit karena memiliki fisik yang kuat. Suku Anak Dalam Batin Sembilan menggunakan sumber alam sebagai pengotan tradisional secara turun temurun, contohnya Gaharu (Aquilaria malaccensis Lam), Akar Mejan (Alyxia stellate Roem. \& Schult), Capo (Blumea balsamifera), Polay (Alstonia scholaris (L.) R.Br), Dedaup (Bauhinia variegata L), Akar Kelkunyit (Arcangelisia flava Merr), Pasak Bumi (Eurycoma longifolia Jack), Keduduk (Melastoma malabatrichum L), Melati Hutan (Jasminum sambac (L.) Aiton), Akar Serekan (Arcangelisia flava (L.) Merr), Daun Mempat (Garcinia sp), Meribungan (Callerya atropurpurea), Sengkuang (Dracontomelon dao).

\section{Gaharu (Aquilaria malaccensis Lam)}


Journal of Healthcare Technology and Medicine Vol. 6 No. 2 Oktober 2020

Universitas Ubudiyah Indonesia

e-ISSN : 2615-109X

Gaharu pada masyarakat di SAD Batin Sembilan dimanfaatkan sebagai pengobatan untuk penyakit darah tinggi dan kolesterol, cara penggunaannya yaitu daun atau akar direbus menggunakan segelas air lalu diminum. Beberapa kandungan yang terdapat dalam gaharu antara lain alkaloid, terpenoid, saponin dan juga tanin. Kandungan alkaloid memiliki fungsi untuk menurunkan kadar kolesterol (Yusuf, Jayuska, et al 2016)

2. Akar Mejan (Alyxia stellate Roem. \& Schult)

Akar Mejan pada masyarakat di SAD Batin Sembilan dimanfaatkan sebagai pengobatan untuk penyakit ambeien serta cara penggolahannya yaitu akar direbus lalu diminum dalam keadaan hangat. Kandungan kimia yang terdapat pada akar mejan ini antara lain alkaloid dan flavonoid, senyawa alkaloid dipercaya dapat menyembuhkan ambein (Fauzi, Widodo, et al, 2019). Selain bagian diatas tidak menutup kemungkinan bagian lain juga dapat digunakan contohnya batang Akar Mejan itu sendiri pun dapat juga digunakan (Ratnasari, Kartikawati, et al, 2017).

\section{Capo (Blumea balsamifera)}

Capo pada masyarakat di SAD Batin Sembilan dimanfaatkan sebagai pengobatan untuk penyakit panas dalam serta cara penggolahannya yaitu daun atau batang direbus dan diminum atau bisa juga dengan cara daun ditumbuk dan diletakkan dibagian yang sakit. Senyawa yang terdapat dalam tumbuhan capo ini adalah flavonoid, minyak essensial dan terpenoid yang dipercaya sebagai pengobatan panas dalam. Bagian yang biasa digunakan pada tumbuhan Capo sendiri yaitu daunnya yang dikenal dengan seribu manfaat (Sukma, 2015).

4. Polay (Alstonia scholaris (L.) R.Br)

Polay pada masyarakat di SAD Batin Sembilan dimanfaatkan sebagai pengobatan untuk penyakit tersengat tawon serta cara penggunaannya yaitu batang dikikis lalu diambil getahnya dan diletakkan dibagian yang tersengat tawon bisa 
Journal of Healthcare Technology and Medicine Vol. 6 No. 2 Oktober 2020

Universitas Ubudiyah Indonesia

e-ISSN : 2615-109X

juga dengan cara menumbuk daun lalu diletakkan dibagian yang tersengat. Selain cara penggunaan yang telah dijelaskan diatas juga terdapat manfaat selanjutnya yaitu Polay kadang-kadang dipakai oleh ibu-ibu untuk membuat bayi berhenti menyusui karena memiliki rasa pahit. Kandungan kimia yang terdapat pada tumbuhan polay ini antara lain flavonoid dan polifenol(Kinho, Diah et al., 2011).

\section{Dedaup (Bauhinia variegata $L$ )}

Dedaup pada masyarakat di SAD Batin Sembilan dimanfaatkan sebagai pengobatan untuk penyakit demam panas serta cara penggunaannya yaitu akar dikikis lalu hasil kikisannya dimasukkan kedalam air lalu diminum jika penggunaannya dengan daun diusap dibagian yang panas sedangkan jika dengan batang direndam menggunakan air hangat sebanyak segelas lalu diminum. Kandungan kimia yang yang terdapat pada tumbuhan dedaup ini antara lain flavonoid, kumarin, fenolik dan juga tanin (Biswas, Giri, et al, 2017).

6. Akar Kelkunyit (Arcangelisia flava Merr)

Akar Kelkunyit pada masyarakat di SAD Batin Sembilan dimanfaatkan sebagai pengobatan untuk penyakit sakit kuning serta cara penggunaannya yaitu akar direndam menggunakan segelas air hangat lalu diminum. Kandungan kimia yang terdapat pada akar kelkunyit antara lain saponin, flavonoid, tanin, steroid dan juga alkaloid. Pada umumnya penggunaan batang kayu kuning untuk pengobatan dari dalam dengan cara minum air rebusannya. Di Jawa tumbuhan ini dipergunakan sebagai obat sariawan (Widi, 2006). Dari sini dapat dibuktikan jika obat tradisional Indonesia sangat beragam macam manfaatnya (Kaharap, Mambo, et al 2016).

\section{Pasak Bumi (Eurycoma longifolia Jack)}


Journal of Healthcare Technology and Medicine Vol. 6 No. 2 Oktober 2020

Universitas Ubudiyah Indonesia

e-ISSN : 2615-109X

Pasak Bumi pada masyarakat di SAD Batin Sembilan dimanfaatkan sebagai pengobatan untuk penyakit malaria cara penggunaannya yaitu dengan cara batang pasak bumi dikikis dan direndam menggunakan segelas air hangat lalu diminum. Selain itu, secara tradisional masyarakat juga memanfaatkan pasak bumi untuk menurunkan tekanan darah. Senyawa kimia yang terdapat pada tumbuhan ini adalah quassinoid yang bersifat antiinflamasi yaitu eurycomaosida(Panjaitan \& Zulfan, 2015).

8. Keduduk (Melastoma malabatrichum L)

Keduduk pada masyarakat di SAD Batin Sembilan dimanfaatkan sebagai pengobatan untuk penyakit muntahber cara penggunaannya yaitu daun atau akar keduduk direndam dengan segelas air hangat. Kandungan kimia yang terdapat dalam tumbuhan ini antara lain flavonoid. Nama-nama keduduk memang beragam di berbagai daerah namun manfaatnya disetiap daerah di Indonesia terkenal banyak sekali contohnya di Toraja sendiri tumbuhan ini dimanfaatkan untuk pengobatan penyakit diare, sariawan sampai dengan keputihan (Tambaru, 2017).

9. Melati Hutan (Jasminum sambac (L.) Aiton)

Melati Hutan pada masyarakat di SAD Batin Sembilan dimanfaatkan sebagai pengobatan untuk penyakit sakit kepala serta cara penggolahannya yaitu batang melati hutan dikikis setelah itu direndam dan diteteskan kemata (Irwan Lovadi, 2015). Senyawa kimia yang terdapat dalam melati hutan ini antara lain saponin, terpenoid, steroid dan juga alkaloid. Pengobatan tradisonal menggunakan melati hutan ini biasanya menggunakan daun dari melati hutan dengan cara daun diremas dan dibalurkan pada bagian yang panas (Meisia \& Ifadatin, 2020)

10. Akar Serekan (Arcangelisia flava (L.) Merr) 
Journal of Healthcare Technology and Medicine Vol. 6 No. 2 Oktober 2020

Universitas Ubudiyah Indonesia

e-ISSN : 2615-109X

Akar Serekan pada masyarakat di SAD Batin Sembilan dimanfaatkan sebagai pengobatan untuk penyakit panas dalam dan pendarahan serta cara penggolahannya yaitu pada akar ada getah warna meah lalu dioleskan kebagian pendarahan sedangkan untuk panas dalam caranya dengan direndam menggunakan segelas air hangat lalu diminum. Kandungan kimia yang terdapat dalam akar serekan ini adalah flavonoid, terpenoid serta alkaloid (Subiandono \& Heriyanto, 2016). Selanjutnya pemanfaatan akar serekan biasanya digunakan untuk penyakit demam serta bagian yang digunakan adalah batang yaitu dengan cara batang diiris dan dikeringkan selanjutnya diseduh dan dapat diminum dalam keadaan hangat (Fadilah., Lovadi, et $a l, 2015)$.

\section{Daun Mempat (Garcinia sp)}

Daun mempat pada masyarakat di SAD Batin Sembilan dimanfaatkan sebagai pengobatan untuk penyakit diare akut cara penggunaannya yaitu akar dan dan daun direndam menggunakan segelas air hangat lalu diminum. Kandungan kimia yang terdapat dalam daun mempat ini adalah xanton yang sangat dibutuhkan untuk penyeimbang pro-oxidant yang dikenal sebagai radikal bebas (Iswandono, Muhammad Zuhud, et al, 2015).

\section{Meribungan (Callerya atropurpurea)}

Meribungan pada masyarakat di SAD Batin Sembilan dimanfaatkan sebagai pengobatan untuk penyakit demam dan cara penggunaanya yaitu akar dan daun direndam menggunakan segelas air hangat lalu diminum. Bagian dari meribungan sendiri yang biasa digunakan adalah daun dan akar. Senyawa kimia yang terdapat pada tumbuhan ini antara lain flavonoid, minyak essensial dan terpenoid (Farida, 2013). 
Journal of Healthcare Technology and Medicine Vol. 6 No. 2 Oktober 2020

Universitas Ubudiyah Indonesia

e-ISSN : 2615-109X

\section{Sengkuang (Dracontomelon dao)}

Sengkuang pada masyarakat di SAD Batin Sembilan dimanfaatkan sebagai pengobatan untuk penyakit kanker serta cara penggunaanya yaitu akar direndam menggunakan segelas air hangat lalu diminum. Khasiat tumbuhan obat dalam menyembuhkan penyakit sangat

bervariasi dari yang hanya sekedar untuk menghilangkan bau badan, gatalgatal, luka memar, hipertensi, batuk dan berak darah hingga infeksi perut dan tumor. Senyawa kimia yang terdapat pada tumbuhan sengkuang ini antara lain alkaloid dan terpenoid. (Farida, 2013).

\begin{tabular}{|c|c|c|c|c|c|c|}
\hline No & Nama Lokal & Nama Ilmiah & Famili & Manfaat & Bagian Yang Digunakan & Cara Pengolahan dan Penggunaan \\
\hline 1. & Gaharu & $\begin{array}{l}\text { Aquilaria } \\
\text { malaccensis } \\
\text { Lam }\end{array}$ & Thymelaeaceae & $\begin{array}{l}\text { Darah Tinggi, } \\
\text { Kolesterol }\end{array}$ & Daun dan Akar & $\begin{array}{l}\text { Daun atau akar direbus menggunakan } \\
\text { segelas air lalu diminum }\end{array}$ \\
\hline 2. & Akar Mejan & $\begin{array}{l}\text { Alyxia stellate } \\
\text { Roem. \& Schult }\end{array}$ & Apocynaceae & Ambeien & Akar & $\begin{array}{l}\text { Akar direbus lalu minum dengan } \\
\text { segelas air, minum selagi hangat }\end{array}$ \\
\hline 3. & Capo & $\begin{array}{l}\text { Blumea } \\
\text { balsamifera }\end{array}$ & Asteraceae & Panas dalam & Daun atau Batang & $\begin{array}{l}\text { Daun atau batang direbus dan diminum } \\
\text { atau bisa juga ditumbuk dan diletakkan } \\
\text { dibagian yang sakit }\end{array}$ \\
\hline 4. & Polay & $\begin{array}{l}\text { Alstonia } \\
\text { scholaris (L.) } \\
\text { R.Br }\end{array}$ & Apocynaceae & Sengat tawon & Getah atau daun & $\begin{array}{l}\text { Batang dikikis, diambil getah dan } \\
\text { diletakkan dibagian yang tersengat } \\
\text { tawon bisa juga dengan menumbuk } \\
\text { daun lalu diletakkan dibagian yang } \\
\text { tersengat }\end{array}$ \\
\hline 5. & Dedaup & $\begin{array}{l}\text { Bauhinia } \\
\text { variegata } L\end{array}$ & Fabaceae & Demam panas & Akar, daun dan batang & $\begin{array}{l}\text { Akar dikikis dan hasil kikisannya } \\
\text { dimasukkan kedalam air lalu diminum } \\
\text { jika penggunaannya dengan daun } \\
\text { diusap dibagian yang panas sedangkan } \\
\text { jika dengan batang direndam } \\
\text { menggunakan air hangat sebanyak } \\
\text { segelas lalu diminum }\end{array}$ \\
\hline 6. & $\begin{array}{l}\text { Akar } \\
\text { kelkunyit }\end{array}$ & $\begin{array}{l}\text { Arcangelisia } \\
\text { flava Merr }\end{array}$ & Menispermaceae & Sakit kuning & Akar & $\begin{array}{l}\text { Akar direndam menggunakan segelas } \\
\text { air hangat lalu diminum }\end{array}$ \\
\hline 7. & Pasak Bumi & $\begin{array}{l}\text { Eurycoma } \\
\text { longifolia Jack }\end{array}$ & Simaroubaceae & Malaria & Batang & $\begin{array}{l}\text { Batang pasak bumi dikesik dan } \\
\text { direndam menggunakan segelas air } \\
\text { hangat lalu diminum }\end{array}$ \\
\hline 8. & Keduduk & $\begin{array}{l}\text { Melastoma } \\
\text { malabatrichum } \\
\text { L }\end{array}$ & Melastomataceae & Muntahber & Daun atau Akar & $\begin{array}{l}\text { Daun atau Akar keduduk direndam } \\
\text { dengan segelas air hangat }\end{array}$ \\
\hline 9. & $\begin{array}{l}\text { Melati } \\
\text { Hutan }\end{array}$ & $\begin{array}{l}\text { Jasminum } \\
\text { sambac (L.) } \\
\text { Aiton }\end{array}$ & Oleaceae & Sakit Kepala & Batang & $\begin{array}{l}\text { Batang melati hutan dikikis setelah itu } \\
\text { direndam dan diteteskan kemata. }\end{array}$ \\
\hline 10. & $\begin{array}{l}\text { Akar } \\
\text { Serekan }\end{array}$ & $\begin{array}{l}\text { Arcangelisia } \\
\text { flava (L.) Merr }\end{array}$ & Menispermaceae & $\begin{array}{l}\text { Panas dalam, } \\
\text { pendarahan }\end{array}$ & Akar & $\begin{array}{l}\text { Di akar ada getah warna merah lalu } \\
\text { dioleskan kebagian pendarahan } \\
\text { sedangkan untuk panas dalam caranya } \\
\text { dengan direndam dengan segelas air } \\
\text { hangat lalu diminum }\end{array}$ \\
\hline
\end{tabular}


Journal of Healthcare Technology and Medicine Vol. 6 No. 2 Oktober 2020

Universitas Ubudiyah Indonesia

e-ISSN : 2615-109X

\begin{tabular}{|lllllll|}
\hline 11. & $\begin{array}{l}\text { Daun } \\
\text { Mempat }\end{array}$ & Garcinia sp & Clusiaceae & $\begin{array}{l}\text { Diare akut } \\
\text { sampai lemas }\end{array}$ & Daun atau akar & $\begin{array}{l}\text { Akar atau daun direndam menggunakan } \\
\text { segelas air hangat lalu diminum }\end{array}$ \\
\hline 12. & Meribungan & $\begin{array}{l}\text { Callerya } \\
\text { atropurpurea }\end{array}$ & Fabaceae & Demam & Daun dan akar & $\begin{array}{l}\text { Akar dan daun direndam menggunakan } \\
\text { segelas air hangat lalu diminum }\end{array}$ \\
\hline 13. & Sengkuang & $\begin{array}{l}\text { Dracontomelon } \\
\text { dao }\end{array}$ & Anarcardiaceae & Kanker & Akar & $\begin{array}{l}\text { Akar direndam menggunakan segelas } \\
\text { air hangat lalu diminum }\end{array}$ \\
\hline
\end{tabular}

\section{KESIMPULAN}

Tumbuhan obat yang digunakan untuk mengobati penyakit tersebut yaitu, Gaharu (Aquilaria malaccensis Lam), Akar Mejan (Alyxia stellate Roem. \& Schult), Capo (Blumea balsamifera), Polay (Alstonia scholaris (L.) R.Br), Dedaup (Bauhinia variegata L), Akar Kelkunyit (Arcangelisia flava Merr), Pasak Bumi (Eurycoma longifolia Jack), Keduduk (Melastoma malabatrichum L), Melati Hutan (Arcangelisia flava (L.) Merr), Akar Serekan (Arcangelisia flava (L.) Merr), Daun Mempat (Garcinia sp), Meribungan (Callerya atropurpurea), Sengkuang (Dracontomelon dao) dan berdasarkan penelitian yang telah dilakukan di Suku Anak Dalam Batin Sembilan cara pengolahan dan penggunaan tumbuhan obat dilakukan dengan cara tumbuhan direndam dan diminum.

\section{SARAN}

Demi berkembang dan menunjang penelitian Etnofarmasi pada Suku Anak Dalam Batin Sembilan di Hutan Harapan Deesa Bungku, Kecamatan Bajubang Kabupaten Batanghari Provinsi Jambi perlu dilakukan penelitian lebih lanjut untuk mengetahui aktifitas tumbuhan secara spesifik yang digunakan pada Suku Anak Dalam Batin Sembilan sebagai obat tradisional. 
Journal of Healthcare Technology and Medicine Vol. 6 No. 2 Oktober 2020

Universitas Ubudiyah Indonesia

e-ISSN : 2615-109X

\section{DAFTAR PUSTAKA}

Biswas, S. J., Giri, S. K., \& Saha, N. C. (2017). A preliminary study on evaluating the galactagogic and antioxidant properties of Bauhinia variegata leaf extract on lactating mice. 6(6), 85-90.

Fadilah., Lovadi, I., dsn Linda, R. (2015). Pemanfaatan Tumbuhan dalam Pengobatan Tradisional Masyarakat Suku Dayak Kanayatn di Desa Ambawang Kecamatan Kubu Kabupaten Kubu Raya. Protobiont, Journal of Pharmacy, 4(3), 49-59.

Fajrin, M., Ibrahim, N., \& Nugrahani, A. W. (2015). Studi Etnofarmasi Suku Kondo Kecamatan Dondo Kabupaten Tolitoli Sulawesi Tengah. GALENIKA Journal of Pharmacy, 1(2), 92-98.

Farida, W. R. (2013). Diversity of Forest Plants as Feed Resources and Habitat of Protected Mammals in Gumai Pasemah Wildlife Sanctuary, Lahat Regency, South Sumatera. Prosiding Semirata FMIPA Universitas Lampung, 2013 Diversity, 447-456.

Fauzi, F., Widodo, H., \& Haryanti, S. (2019). Kajian Tumbuhan Obat yang Banyak Digunakan untuk Aprodisiaka oleh Beberapa Etnis Indonesia. Media Penelitian Dan Pengembangan Kesehatan, 29(1), 51-64.

Idris, N. (2017). Mengkaji Ulang Pola Komunikasi Pemerintah Dalam Pemberdayaan Suku Anak Dalam Di Provinsi Jambi. Jurnal Penelitian Pers Dan Komunikasi Pembangunan, 21, 37-48.

Irwan Lovadi, A. S. R. L. (2015). Pemanfaatan Tumbuhan Obat Pada Masyarakat Suku Dayak Jangkang Tanjung Di Desa Ribau Kecamatan Kapuas Kabupaten Sanggau. Jurnal Protobiont, 4(2), 1-8.

Iswandono, E., Muhammad Zuhud, E. A., Hikmat, A., \& Kosmaryandi, N. (2015). The Ethnobotany Knowledge of Manggarai Tribe and the Implication Utilization of Forest Plants in The Mountains of Ruteng. Jurnal Ilmu Pertanian Indonesia, 20(3), 171-181.

Kaharap, A. D., Mambo, C., \& Nangoy, E. (2016). Uji efek antibakteri ekstrak batang akar kuning (Arcangelisia flava Merr.) terhadap bakteri Staphylococcus aureus dan Escherichia coli. Jurnal E-Biomedik, 4(1).

Kinho, J., \& Diah I.D.A., Supratman T., Harwiyaddin K., Yermias K., Syamsir S., M. C. . (2011). Tumbuhan Obat Tradisional Di Sulawesi Utara Jilid I Julianus Kinho Diah Irawati Dwi Arini Supratman Tabba Harwiyaddin Kama Yermias Kafiar Syamsir Shabri.

Meisia, L., \& Ifadatin, S. (2020). Pemanfaatan Tumbuhan Obat Oleh Masyarakat Suku Melayu Di Desa Sungai Daun Kecamatan Selakau Kabupaten Sambas. Protobiont, 9, 7-16.

Panjaitan, R., \& Zulfan, Z. (2015). "Pemberian Ekstrak Metanol Akar Pasak Bumi Mempertahankan Bobot Badan Induk Mencit Selama Menyusui (Administration Of Eurycoma Longifolia Extracts Stabilized The Body Weight Of Lactating Mice)." Jurnal Veteriner, 16(4), 553-559.

Pujayanti, A. (2005). Lsm internasional dan dilema pelestarian di hutan harapan provinsi jambi. 17-36.

Ratnasari, D., Kartikawati, S., \& Muflihati. (2017). Tumbuhan Obat Khusus Kesehatan Reproduksi Wanita Di Dusun Kayu Baong Desa Pekawai Kecamatan Sayan Kabupaten Melawi. Jurnal Hutan Lestari, 5(2), 499-507.

Subiandono, E., \& Heriyanto, N. M. (2016). Kajian Tumbuhan Obat Akar Kuning (Arcangelisia flava Merr.) di Kelompok Hutan Gelawan, Kabupaten Kampar, Riau. Buletin Plasma Nutfah, 15(1), 43. 
Journal of Healthcare Technology and Medicine Vol. 6 No. 2 Oktober 2020

Universitas Ubudiyah Indonesia

e-ISSN : 2615-109X

Sukma, M. (2015). Asteraceae Yang Dimanfaatkan Sebagai Tumbuhan Obat Di Kecamatan Lubuk Alung Kabupaten Padang Pariaman. Jurnal Stkip Pgri.

Tambaru, E. (2017). Keragaman Jenis Tumbuhan Obat Indigenous Di Sulawesi Selatan. Jurnal Administrasi Dan Kebijakan Kesehatan Indonesia, 8(15), 7-13.

Widi, R. K. (2006). Penjaringan dan Identifikasi Senyawa Alkaloid dalam Batang Kayu Kuning ( Arcangelisia Flava Merr ) ( Screening and Identification of Alkaloid Compounds in Kayu Kuning Stem ( Arcangelisia Flava Merr )). Jurnal ILMU DASAR, 8(1), 24-29.

Yusuf, S., Jayuska, A., \& Idiawati, N. (2016). Isolasi dan Karakteristik Senyawa T 